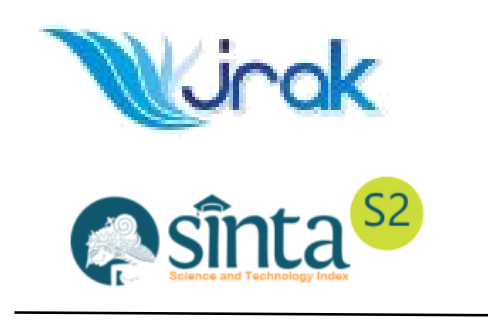

Website:

ejournal.umm.ac.id/index.php/jrak

*Correspondence:

erwin_saraswati@yahoo.com

DOI: $10.22219 /$ jrak.v11i1.14961

Citation:

Saraswati, E., Lestari, A.P., \& Sagitaputri, A. (2021). Does CSR Disclosure Improve Firm's Access To Finance And Reduce Firm Risk?. Jurnal Reviu Akuntansi dan Keuangan, 11(1), 17-29.

Article Process

Submitted:

December 21, 2020

Reviewed:

February 16, 2021

Revised:

April 25, 2021

Accepted:

April 26, 2021

Published:

May 04, 2021

Office:

Department of Accounting University of

Muhammadiyah Malang

GKB 2 Floor 3.

Jalan Raya Tlogomas 246,

Malang, East Java,

Indonesia

P-ISSN: 2615-2223

E-ISSN: 2088-0685
Article Type: Research Paper

\section{DOES CSR DISCLOSURE IMPROVE FIRM'S ACCESS TO FINANCE AND REDUCE FIRM RISK?}

\author{
Erwin Saraswati ${ }^{1 *}$, Anastasia Putri Lestari ${ }^{1}$, Ananda \\ Sagitaputri ${ }^{2}$ \\ Afiliation: \\ ${ }^{1}$ Department of Accounting, University of Brawijaya, Malang, East \\ Java, Indonesia \\ ${ }^{2}$ Department of Accounting, University of Indonesia, Depok, West \\ Java, Indonesia
}

\section{ABSTRACT}

This study aims to find how CSR disclosure affects firm's access to finance and firm risk, using empirical studies. The research uses secondary data from annual report and sustainability report listed in the manufacturing sector in Indonesia Stock Exchange (IDX). By using the purposive sampling method, a sample of 41 firms was obtained or 164 firm-years from 2015 to 2018. The study measures CSR disclosure by both quantity and quality to reflect the overall comprehensibility of the report. Data analysis is done with multiple linear regression method. The result shows that CSR quantity and quality increase a firm's access to finance and reduce firm risk. Extensive and high-quality CSR reports are more favourable to investors, fund providers, and the society as a whole. It is because CSR improves a firm's reputation and reduces agency problem. This supports legitimacy and agency theories. The limitation of this study is that it uses content analysis for CSR measures, so that there is an element of researcher's subjectivity. The results of these findings can be used as a consideration for companies to improve CSR disclosure and policy setting for regulators.

KEYWORDS: Access to Finance; CSR Disclosure; Firm Risk. 


\section{INTRODUCTION}

Over the decades, Corporate Social Responsibility (CSR) have been a global interest for practitioners and researchers (Jo \& Na, 2012). This has caused companies to act in a more ethical and responsible way. However, corporate reporting is often costly and time consuming (García-Sánchez et al., 2019). Companies always prioritize financial considerations in their decision making (Sahut et al., 2019), so it is important that their reporting efforts really make a difference to the bottom line. Nevertheless, studies regarding financial benefits of CSR have resulted in conflicting evidences (Sahut et al., 2019).

Studies in Indonesia found that benefits of CSR disclosure include increases in firm value (Estiasih et al., 2019; Ibrahim et al., 2015; Rosiana et al., 2013), reduced information asymmetry (Kurnianto et al., 2016), and reduced cost of equity for non-liquid companies (Wulandari and Atmini, 2012). However, CSR did not seem to affect cost of debt (Juniarti and Sentosa, 2009), stock prices, and earnings response coefficient (Awuy et al., 2016; Restuti and Nathaniel, 2012) which indicated that Indonesian investors only considered financial aspects and have not paid much attention to CSR. Tarigan and Semuel (2014) found that social and environmental disclosures have a negative impact to financial performance, implying that the cost of doing so exceeded the benefits, at least in the shortterm.

The inconclusive findings from the previous studies have motivated researchers to further study the impacts of disclosing CSR. The current study will look at how CSR disclosures affect firms' access to finance and firm risk, as those are the key drivers of a firm's growth. This has been increasingly important as the level of credit accessibility in Indonesia has continued to decrease. According to the result of Survey Business Activities (SKDU) conducted by Central Bank of Indonesia, the level of credit accessibility has decreased from $7.41 \%$ in the second quarter of 2017 to $4.69 \%$ in the fourth quarter of 2019 . This has caused a phenomenon of financing scarcity.

The financing scarcity can be caused by credit limitations or inability to obtain loans, failure to meet financial market expectations, or liquidity issues due to excessive dependence on bank loans (Lamont et al., 2001). In light of the financing scarcity, it is important that firms be able to promote themselves to financial institutions. One of the ways are through disclosure, as disclosure serves as a signal from management about what to be expected from the company (Rankin et al., 2018). One type of voluntary disclosure that has been increasingly important is sustainable performance reporting (Rankin et al, 2018). This is because some of today's investors do not solely focus on financial performance, but also at how companies perform in terms of environmental, social, and governance (ESG) practices (USSIF, 2019).

The positive effect of CSR disclosure to access to finance has been proven in several studies (Cheng et al., 2014; García-Sánchez et al., 2019; La Rosa et al., 2018). They argue that when company disclose more, more information will be available to investors for their decision making (García-Sánchez et al., 2019). More transparency also means reduced information asymmetry, leading to better access to finance (Cheng et al., 2014).

Companies minimize firm risks to maximize their economic performance (Orlitzky and Benjamin, 2001). Firm risk is defined as the inherent risk of a business due to internal or external factors that potentially affect its profitability (Jo and $\mathrm{Na}, 2012$ ). Firm risk is reflected by the fluctuations in share prices or in internal accounting returns. Today's investors understand that risks are not solely affected by financial performance, but also the

JRAK

11.1 
underlying operations of the business (Orlitzky and Benjamin, 2001). Hence, one way to reduce this risk is to mitigate the potential financial, social, or environmental risks that may arise (Sharfman and Fernando, 2008)

Studies have found that CSR performance and disclosures have negative effect on firm risks. Orlitzky and Benjamin (2001) on a meta-analytic study found that Corporate Social Performance (CSP), such as charitable donations, responsibility to the environment, and fair treatment to employees, had a negative causal relationship with firm risk. Benlemlih et al. (2016) found that Environmental and Social disclosure decreased firms' overall and idiosyncratic risk. They argue that CSR disclosures enhanced reputation and stakeholders' trust, which consequently improved investors' reaction and reduced firm risk.

Legitimacy theory holds the view that a firm would cease to exist if it does not able to maintain the social contract (Rankin et al., 2018). This theory explains that society is shaped through a collectively mutually binding agreement or contract which forms moral expectations and duties (Rozuel, 2013). Rankin et al. (2018) further defines social contract as the implicit and explicit expectation that society holds on how a firm should run their business to be able to survive in the future. Consequently, businesses have responsibilities not only to the shareholders, but also to the workforce, environment and the local surrounding communities (Chan et al., 2013).

This research will focus on manager-lender agency relationship. Rankin et al. (2018) explain that there are a few agency issues that may arise between lender and manager, such as excessive dividend payments, underinvestment, asset substitution, and claim dilution. According to García-Sánchez et al. (2019), when determining the conditions of a debt contract, the lender will assess the ability of the borrowers to meet future payment obligations and potential risks that the company may suffer from. If financial institutions consider the agency problem to be significant, it will result in higher interest rate or the requirement of a collateral (Steijvers and Voordeckers, 2009).

This study will seek evidence on how CSR disclosure affects a firm's access to finance and firm risk in Indonesian context and will take Indonesian listed manufacturing firms from 2015 to 2018 as sample. Manufacturing sector is chosen as it is more prone to changes in economic conditions (Widyasari, 2015). CSR disclosure will be assessed both quantitatively and qualitatively, to provide a more comprehensive assessment for the CSR report (Beretta and Bozzolan, 2008). This research contributes to the literature as there has been relatively lack of study in Indonesia regarding the impact of CSR to access to finance and firm risk. Therefore, the study combines access to finance (Garcia-Sanches, 2018), and firm risk (Jo and $\mathrm{Na}, 2012$ ), because CSR disclosure is expected to facilitate access to finance and reduce corporate risk.

CSR information can be seen from a quantity and quality, because generally assumed that quantity information has an implication its quality (Beretta and Bozzolon, 2008). Quantity shows how much is disclosed which shows the content of the disclosure, both the depth and the breadth of quality (Beretta and Bozzolon, 2008), while quality reflects that level of disclosure that meets the user's needs (Alotaibi and Hussaney, 2016). So, this study uses both.

JRAK According to agency theory, lender-manager agency problems can be mitigated when 11.1 information asymmetry is reduced. One of the ways is through CSR disclosure. CSR reports with better quality will provide better information to the investors and the market (García-Sánchez et al., 2019). Several studies have proven that CSR quantity has a positive effect on firm reputation (Hasseldine et al., 2005) and market capitalization (Alotaibi and 
Hussainey, 2016). Along with these benefits, good CSR performance is also proven to ease the access to finance via enhanced transparency and lower capital constraints (Cheng et al., 2014). The quantity of CSR report can also adequately measure the quality of the report (Beretta and Bozzolan, 2008). Therefore, the hypotheses below was proposed:

H1: CSR report quantity has a positive influence on firms' access to finance.

H2: CSR report quality has a positive influence on firms' access to finance.

Benlemlih et al. (2016) found that extensive environmental and social performance reporting help enhance corporate transparency and increase stakeholder's trust, which in turn mitigate risk within the firm. Jo and $\mathrm{Na}$ (2012) found similar results that engaging in socially responsible programs will enhance a firm's image and reputation, which consequently reduce firm risk. Studies have found that CSR performance and disclosures have negative effect on firm risks. Orlitzky and Benjamin, 2001). The companies which have disclosure of CSR can reduced firm risk for controversial industry (Eriandani and Wijaya, 2021). Hence, the hypotheses below was proposed:

H3: CSR Report Quantity has a negative influence on firm risk.

H4: CSR Report quality has a negative influence on firm risk.

\section{METHOD}

The population for this research was Indonesian firms that were listed in the manufacturing sector of the Indonesian Stock Exchange (IDX) from 2015 to 2018. The research used purposive sampling with the following criteria:

1. Firms were continually listed in the manufacturing sector in the Indonesia Stock Exchange

2. Firms published CSR report as part of their annual report or have their stand-alone report published in the GRI Database from 2015 to 2018.

The manufacturing sector was chosen because of their sensitivity to the economic condition both from internal and external causes. The CSR report quality data was collected from the GRI database. The financial reports were obtained from Indonesia Stock Exchange Database and the firms' official website. Historical stock price data was obtained from the Yahoo Finance website.

The dependent variable, CSR report quality and quantity were measured using the method by Raar (2002) by giving scores to the CSR report based on the quantity and the quality of the content of the CSR report. The content was categorized into different categories, which will be judged based on the quantity and quality of each different category. The categories were displayed in Table 1.

The 'Eninar' category responded to a 'Yes' or 'No' question. The unit of analysis that was used for the other 8 categories in determining the quantity of disclosure is the combination of individual sentences, which then is accumulated into a paragraph, half a page, one page, or more than one page. The unit of analysis that was used in determining the quality of the disclosure is by determining whether the discussion was in the form of monetary, nonmonetary, or qualitative discussion. The table below shows a further definition of the analysis methods

JRAK 
Environmental issues in the annual Any discussion included in the annual report report (Eninar) warranted a "yes" response

Key indicators (Keyind)
Profile (Profile)

Policies (Policies)

External Relations (Extrel)

Management performance (Manperf)
Description of environmental, social issues and impacts associated with operations products and/or services

Indicators of anticipated environmental performance

Inputs and emissions relating to energy, waste materials, water, solid waste, hazardous waste, fuel, air eco-efficiency benchmarks, firm, division, or product related)

life cycle impacts \pm products or services

Environmental issues included:

reorganizational structure

type of products marketed industry group

Mission statements, values, environmental management systems e.g., ISO 14000), external certification, performance measurement standards, risk assessment criteria, auditing, training

Stakeholder requirements, stakeholder communication, benchmarks, consultation, and information issues

Pertaining to compliance:

Includes penalties and awards, compliance with international declarations, treaties, national, local

Remediation costs, environmental liabilities, oil spills, accidents, emissions

Performance against internal standards. Awards, recognition, etc.

Occupational health and safety Any comments that relate to occupational health (Ochhans) and safety issues, including plans, objectives, goals, and performance

Product performance (Prodper)

Sustainability (Sustain)

\section{JRAK} Any comments that relate to occupational health and safety issues, including plans, objectives, goals, and performance

Integration of economic and social goals and values, linkage with long-term decision-making and performance issues
Table 1.

Schema Of

Categories

And

Definition

\section{1}




\begin{tabular}{|c|c|c|}
\hline $\begin{array}{c}\text { Quantity of } \\
\text { disclosure } \\
\text { "how much" }\end{array}$ & $\begin{array}{l}\text { Quality of disclosure } \\
\text { "how measured" }\end{array}$ & Quality definition \\
\hline $1=$ sentence & $1=$ monetary & $\begin{array}{l}\text { Disclosure } \\
\text { monetary/currency terms }\end{array}$ \\
\hline $2=$ paragraph & $2=$ non-monetary & $\begin{array}{l}\text { Quantified in numeric terms of } \\
\text { weight, volume, size, etc. but } \\
\text { not financial/currency. }\end{array}$ \\
\hline $3=$ half A4 page & $3=$ qualitative only & Descriptive prose only \\
\hline $4=1 \mathrm{~A} 4$ page & $4=$ qualitative and monetary & Descriptive prose and currency \\
\hline \multirow[t]{2}{*}{$5 \geq 1$ A4 page } & $\begin{array}{l}5=\text { qualitative and non- } \\
\text { monetary } \\
6=\text { monetary and non- } \\
\text { monetary }\end{array}$ & $\begin{array}{l}\text { Descriptive prose and numeric } \\
\text { terms } \\
\text { A combination of currency } \\
\text { and numeric terms }\end{array}$ \\
\hline & $\begin{array}{l}7=\text { qualitative, monetary and } \\
\text { non-monetary }\end{array}$ & $\begin{array}{l}\text { Descriptive prose, financial } \\
\text { and numeric terms }\end{array}$ \\
\hline
\end{tabular}

The first independent variable in this study, access to finance, was measured using the Kaplan-Zingales (KZ) Index. KZ index was the method used to measure financial constraint and distress by utilizing five accounting ratios, which are cash holding to total capital, cash flow to total capital, debt to total capital, dividends to total capital and market to book ratio (García-Sánchez et al., 2019). The higher amount of KZ index, the higher financial constraint. The formula for the calculating the KZ Index was as follows:

$$
\text { KZ Index }=-1.002 \frac{C F_{\mathrm{iR}}}{A_{\mathrm{it}-1}}-39.638 \frac{D I V_{\mathrm{iR}}}{A_{\mathrm{it}}-1}-1.315 \frac{C_{\mathrm{iR}}}{A_{\mathrm{it}-1}}+3.139 \mathrm{LEV}_{\mathrm{it}}+0.238 \mathrm{Q}_{\mathrm{it}}
$$

Where:

$$
\begin{array}{ll}
\text { CF } & \text { Cash flow } \\
\text { A } & \text { Total asset } \\
\text { DIV } & \text { Cash dividend paid by the company in the current year } \\
\text { C } & \text { Cash balances } \\
\text { LEV } & \text { Level of leverage in firm's capital structure } \\
\text { Q } & \text { Market value of equity }
\end{array}
$$

The second independent variable, firm risk, was measured using the method used by Benlemlih et al. (2016). A firm's total risk is a combination of both market risk and firms' idiosyncratic risk, which was measured by the standard deviation of the firms' daily stock return in a particular year.

$$
\begin{gathered}
\text { Firm Risk }=\sigma R_{\text {it }} \\
\text { where } \\
\mathrm{R}=\left(\frac{\text { Closing Price }}{\text { Closing Price }_{\bar{D}-1}}\right)-1
\end{gathered}
$$


The control variable used in this study is firm size. Firm size was measured by the natural

23 logarithm of a firm's total asset. Larger firms are expected to be less exposed to risk as they are more capable in management and have more resources to invest in non-profit making activities (Hussain et al., 2018; Jo and Na, 2012).

The data were analysed using Multiple Regression Method. Model 1 below will test the effect of CSR quantity and quality to access to finance:

$$
\text { KZ Index }=\alpha+\beta 1 C S R R \_ \text {Quantity }+\beta 2 C S R R \_ \text {Quality }+\beta 3 S I Z E+\varepsilon
$$

Model 2 below will test the effect of CSR quantity and quality to firm risk:

Where:

$$
\text { Firm Risk }=\alpha-\beta 1 C S R R \_ \text {uantity }-\beta 2 C S R R \_ \text {uality }+\beta 3 S I Z E+\varepsilon
$$

$$
\begin{array}{lc}
\text { KZ Index } & \text { Firms Access to Finance } \\
\text { CSRR_Quality } & \text { CSR report quality score } \\
\text { CSRR_Quantity } & \text { CSR report quantity score } \\
\text { SIZE } & \text { Firm Size }
\end{array}
$$

\section{RESULTS AND DISCUSSION}

The sample included in this study consisted of firms listed in the manufacturing sector of Indonesian Stock Exchange (IDX) between 2015 and 2018, which published an annual report and CSR report on those years, and had all the information available for the measurement of the variables. The number of samples used was 41 , based on the sampling selection in the table 3 below:

\begin{tabular}{lcc}
\hline & Sample Criteria & Total \\
\hline Population & 150
\end{tabular}

Sample Criteria:

Firms that are not listed in/delisted from the manufacturing sector in the Indonesia Stock Exchange in 2015 to 2018

Firms that did not publish annual reports in 2015-2018

Firms that did not publish CSR report as part of their annual report or had their stand-alone report published in the GRI Database or had incomplete sets of reports in 2015-2018

Firm that did not have complete data to be used to measure the variables

Total Sample per year

Table 3.

Total observations (firm-years) 
The descriptive result of the variables that were being studied are shown on the table 4 below.

Table 4.

\begin{tabular}{lccccc}
\hline & N & Minimum & Maximum & Mean & Std. Deviation \\
\hline CSR Quantity & 164 & 1 & 39 & 18.305 & 10.796 \\
CSR Quality & 164 & 3 & 44 & 19.524 & 9.579 \\
KZ Index & 164 & -9.420 & 19.410 & 0.473 & 4.293 \\
Firm Risk & 164 & 0.004 & 0.661 & 0.031 & 0.058 \\
Firm Size & 164 & 26 & 33 & 29.171 & 1.736 \\
\hline
\end{tabular}

CSR quantity data have a minimum of 1 and maximum of 39, with an average of 18. CSR quantity data has a minimum of 3 and maximum of 44, with an average of 20 . In sum, voluntary disclosure practices of the sample companies are highly varied, but on average are relatively low in both quantity and quality. KZ Index data show a high variation, with a minimum of negative 9, a maximum of positive 19, and an average of positive 0.47 . As explained earlier, higher KZ Index means more financial constraint, which also leads to higher financial distress (Kim and Park, 2015). Firm risk data show little variation, with a minimum of 0.004 , a maximum of 0.661 , and an average of 0.031 . The control variable firm size also shows little variation. In absolute terms, the smallest sample firm has a total asset of Indonesian Rupiah (IDR) 195 billion, while the biggest firm has IDR 214 trillion, and the average firm has IDR 4 trillion.

The normality testing was done using the Normal P-Plot Regression by looking whether the dots shown in the graph follows the pattern of a diagonal line. The results of the test for both dependent variables are shown in the Figure 1 below. Since there were no values which deviate the straight lines, the data are normally distributed.

A multicollinearity test was done to find out whether there is a correlation between the independent variables. Multicollinearity exists when the Variance Inflation Factor (VIF) value is greater than 10 . The multicollinearity test result for the independent variables is shown on table 5 . Since the VIF values are below 10 , there were no multicollinearity issues in the variables.

Figure 1.

Normality

Testing

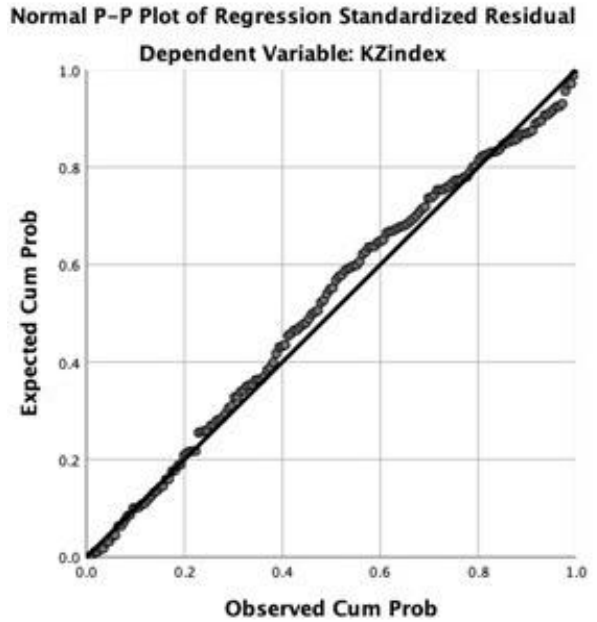

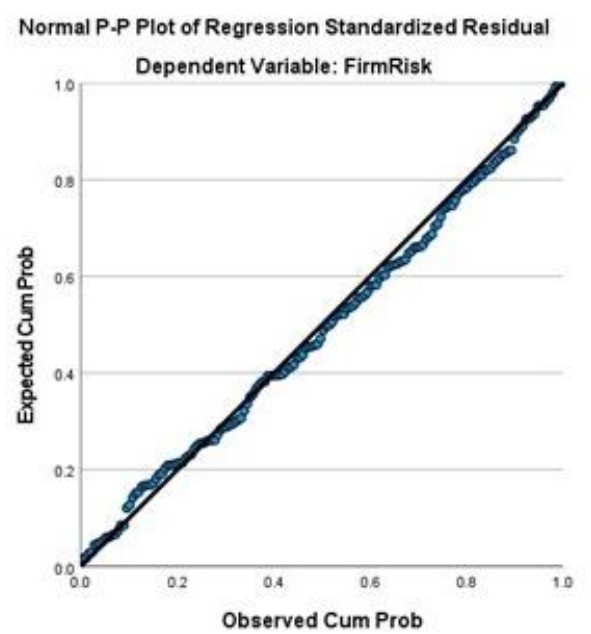

JRAK 
25

\begin{tabular}{|c|c|c|c|}
\hline \multirow{2}{*}{ Independent Variables } & \multicolumn{2}{|c|}{ Collinearity Statistics } & \multirow{5}{*}{$\begin{array}{l}\text { Table } 5 . \\
\text { Multicollinear } \\
\text { ity Testing }\end{array}$} \\
\hline & Tolerance & VIF & \\
\hline CSR Quantity & 0.243 & 4.112 & \\
\hline CSR Quality & 0.252 & 3.970 & \\
\hline Size & 0.847 & 1.180 & \\
\hline
\end{tabular}

Heteroscedasticity is unequal variance of the data along the regression line. The heteroscedasticity testing used scatterplots, and a heteroskedastic data occurs when the scatterplots form a shape, e.g., a cone or a fan. The testing result shows randomly spread scatter-plot, hence the data was homoscedastic.

Table 6 below shows the regression result for Model 1 and Model 2.

\begin{tabular}{lcc}
\hline \multicolumn{1}{c}{ Variables } & KZ Index & Firm Risk \\
\hline Constant & -17.694 & -1.753 \\
t Value & -1.821 & -0.736 \\
& $(0.070)$ & $(0.463)$ \\
CSR Quantity & 0.899 & -0.250 \\
t Value & 2.041 & -2.311 \\
& $(0.043)^{* *}$ & $(0.022)^{* *}$ \\
CSR Quality & 1.894 & -0.368 \\
t Value & 3.540 & -2.810 \\
& $(0.001)^{* * *}$ & $(-0.006)^{* * *}$ \\
Firm Size & 3.230 & -0.092 \\
t Value & 1.096 & -0.128 \\
& $(0.275)$ & $(0.898)$ \\
Leverage & 0.065 & 0.094 \\
t Value & 0.327 & 1.957 \\
& $(0.744)$ & $(0.052)^{*}$ \\
\hline Adj. R & 0.435 & 0.373 \\
F Value & 42.840 & 33.256 \\
& $(0.000)^{* * *}$ & $(0.000)^{* * *}$ \\
\hline$*$ a & & \\
\hline
\end{tabular}

*significant at $\alpha=10 \%$

$\mathbf{1 1 . 1} * *$ significant at $\alpha=5 \%$

Table 6.

Regression

Result 
The regression result shows that CSR quantity and quality have significant positive effects to a firm's access to finance with $95 \%$ and $99 \%$ confidence level, respectively. Thus, hypothesis 1 and 2 are accepted. The results are consistent with García-Sánchez et al. (2019) and Cheng et al. (2014). When firms publish complete CSR reports, they provide better information to the stakeholders, such as investors (García-Sánchez et al., 2019). Good CSR information attributes will also reduce agency cost and information asymmetry (Cheng et al., 2014). With better responses from the financial markets and creditors, firms will have better access to finance.

The regression result of the dependent variable firm risk shows that CSR quantity and quality significantly reduces firm risk with $95 \%$ and $99 \%$ confidence level, respectively. This result supports hypothesis 3 and 4. This result aligns with Benlemlih et al. (2016) and Jo and $\mathrm{Na}$ (2012). Jo and $\mathrm{Na}$ (2012) suggests that company executives who are committed to CSR will reduce the firm risk in the long run. CSR disclosure quantity and quality helps mitigate firm risk through better transparency and improved stakeholder trust (Benlemlih et al., 2016) and enhanced reputation (Jo and Na, 2012). The result also aligns with La Rosa et al. (2018) which finds that complete CSR information will reduce cost of debt.

In sum, the result suggests that external parties consider companies' CSR disclosure when making financing decisions. From the agency theory point of view, extensive and highquality CSR disclosure will reduce agency cost and mitigate agency problem. This will result in lower firm risk and easier access to finance.

The result also supports the stakeholder and legitimacy theories. CSR disclosure helps companies engage their stakeholders and meet society expectations. When the expectations of the stakeholder and society are met, firms will be more likely to survive and grow, attracting investors and creditors. Hence, CSR disclosure helps decrease firm risk and financial constraint. The results of this study indicate that the disclosure of CSR both in quantity and quality makes it easier for firm access to finance and reduced the risk.

Lastly, this study finds that the control variable of firm size is not found to significantly affect both access to finance and firm risk. This result contrasts Jo and $\mathrm{Na}$ (2012) which finds that firm size reduces firm risk, and Giang et al. (2019) which finds that smaller firms have difficulty obtaining access to finance. The variation could be caused by the sample size, as larger sample size may yield different results.

\section{CONCLUSION}

This study aims to provide evidence for the relationship between Corporate Social Responsibility (CSR) report quality and quantity with firm's access to finance and firm risk. The study is conducted on 41 the firms listed in the manufacturing sector of the Indonesia Stock Exchange (IDX) from 2015-2018 or 164 firm-years. The result shows that CSR report quantity and quality improve firm's access to finance and reduce firm risk, which is consistent with the previous studies. The result indicates that fund providers and investors have already considered sustainability when assessing a firm's performance. Hence, lengthier and better CSR reports will ease firms' access to financial services and reduce the perceived risk by investors.

This study provides evidence that CSR report serves beyond compliance to regulation. CSR reports are impactful for the long-term sustainability of businesses. Firms which publish 
financial services and lower perceived risk. Therefore, firms should pay more attention to their CSR activities and reports.

This study uses a scoring system in order to measure the quality of the CSR report. It may have a component of subjectivity when it comes to the scores and therefore decreases the accuracy of the outcome. For future research, it is recommended that the valuation for CSR quality and quantity be done using multiple measurers to eliminate bias and inaccuracy.

The limitation also comes from the lack of a more generalizable and reliable measure of CSR quality. The method that was used in this study was chosen as it is believed to have reflected one of the most reliable guidelines in writing the CSR report, which is the GRI Guideline. This study population is also limited to the firms in the manufacturing sector, which may not reflect the condition for firms in another sector. Future studies are recommended to use other measures of performance, such as ROI. Future researches can consider SMEs as sample and environmental sensitivity as a variable.

\section{REFERENCES}

Alotaibi, O. ., and Hussainey, K. (2016). Determinants of CSR disclosure quantity and quality: Evidence from non-financial listed firms in Saudi Arabia. International Journal of Disclosure and Governance, 13(4), 364-393. https://doi.org/10.1057/jdg.2016.2

Awuy, V. P., Sayekti, Y., and Purnamawati, I. (2016). Pengaruh Pengungkapan Corporate Social Responsibility (CSR) Terhadap Earnings Response Coefficient (ERC) (Suatu Studi Empiris Pada Perusahaan Pertambangan yang Terdaftar di Bursa Efek Indonesia Pada Tahun 2010-2013). Jurnal Akuntansi Dan Keuangan, 18(1), 15-26. https://doi.org/https://doi.org/10.9744/jak.18.1.15-26

Benlemlih, M., Shaukat, A., Qiu, Y., and Trojanowski, G. (2016). Environmental and Social Disclosures and Firm Risk. Journal of Business Ethics2, 152(3), 613-626. https://doi.org/10.1007/s10551-016-3285-5

Beretta, S., and Bozzolan, S. (2008). Quality versus Quantity: The Case of ForwardLooking Disclosure. Journal of Accounting, Auditing and Finance, 23(3), 333-376. https://doi.org/10.1177/0148558x0802300304

Chan, M., Watson, J., and Woodliff, D. (2013). Corporate Governance Quality and CSR Disclosures. Journal of Business Ethics, 125(1), 59-73. https://doi.org/10.1007/s10551013-1887-8

Cheng, B., Ioannou, I., and Serafeim, G. (2014). Corporate Social Responsibility and Access to Finance. Strategic Management Journal, 35(1), 1-23.

Eriandani, Rizky dan Liliana Inggrit Wijaya. (2021). Corporate Social Responsibility and Firm Risk: Controversial versus noncontroversial Industries. Journal of Asean Finance, Economics and Business, Vol 8 No 3 (2021).

Estiasih, S. P., Yuniarsih, N., and Wajdi, M. B. N. (2019). The Influence of Corporate Social Responsibility Disclosure, Managerial Ownership and Firm Size on Firm Value

JRAK in Indonesia Stock Exchange. International Journal of Innovation, Creativity and Change, 9(9).

11.1 García-Sánchez, I., Hussain, N., Martínez-Ferrero, J., and Ruiz-Barbadillo, E. (2019). Impact of disclosure and assurance quality of corporate sustainability reports on access to finance. Corporate Social Responsibility and Environmental Management, 26(4), 832- 
848. https://doi.org/https://doi.org/10.1002/csr.1724

Giang, M., Trung, B., Yoshida, Y., Xuan, T., and Que, M. (2019). The Causal Effect of Access to Finance on Productivity of Small and Medium Enterprises in Vietnam. Sustainability, 11(19). https://doi.org/10.3390/su11195451

Hasseldine, J., Salama, A., and Toms, S. (2005). Quantity versus Quality: The Impact of Environmental Disclosures on the reputations of UK plcs. British Accounting Review, 37(2), 231-248.

Hussain, N., Rigoni, U., and Orij, R. P. (2018). Corporate governance and sustainability performance: Analysis of triple bottom line performance. Journal of Business Ethics, 149(2), 411-432. https://doi.org/https://doi.org/10.1007/ s10551-016-3099-5

Ibrahim, M., Solikahan, E. Z., and Widyatama, A. (2015). Karakteristik Perusahaan, Luas Pengungkapan Corporate Social Responsibility, dan Nilai Perusahaan. Jurnal Akuntansi Multiparadigma, 6(1). https://doi.org/https://doi.org/10.18202/jamal.2015.04.6008

Jo, H., and Na, H. (2012). Does CSR Reduce Firm Risk? Evidence from Controversial Industry Sectors. Journal of Business Ethics, 110(4), 441-456. https://doi.org/10.1007/s10551-012-1492-2

Juniarti, and Sentosa, A. A. (2009). Pengaruh Good Corporate Governance, Voluntary Disclosure terhadap Biaya Hutang (Costs of Debt). Jurnal Akuntansi Dan Keuangan, 11(2), 88-100.

Kim, J., and Park, J. L. (2015). How do financial constraint and distress measures compare? Investment Management and Financial Innovations, 12(2), 41-50.

Kurnianto, S., Sutrisno, S., and Saraswati, E. (2016). Luas Pengungkapan Dan Dampaknya Terhadap Asimetri Informasi Perusahaan Di Bursa Efek Indonesia. Jurnal Akuntansi Multiparadigma, 7(1), 142-155.

La Rosa, F., Liberatore, G., Mazzi, F., and Terzani, S. (2018). The impact of corporate social performance on the cost of debt and access to debt financing for listed European non-financial firms. European Management Journal, 36(4), 519-529. https://doi.org/10.1016/j.emj.2017.09.007

Lamont, O., Polk, C., and Saaá-Requejo, J. (2001). Financial Constraints and Stock Returns. Review of Financial Studies, 14(2), 529-554. https://doi.org/10.1093/rfs/14.2.529

Mainardes, W. E., Alves, H., and Raposo, M. (2012). A model for stakeholder classification and stakeholder relationships. Management Decision, 50(10), 1861-1879. https://doi.org/10.1108/00251741211279648

Orlitzky, M., and Benjamin, J. D. (2001). Corporate social performance and firm risk: A meta-analytic review. Business and Society, 40(4), 369-396.

Raar, J. (2002). Environmental Initiative: Towards Triple Bottom Line Reporting. Corporate Communications: An International Journal, 7(3), 169-183.

Rankin, M., Ferlauto, K., McGowan, S., and Stanton, P. (2018). Contemporary Issues in Accounting 2nd ed. John Wiley and Sons Australia, Ltd.

Restuti, M. M. D., and Nathaniel, C. (2012). Pengaruh Pengungkapan Corporate Social Responsibility Terhadap Earning Response Coefficient. Jurnal Dinamika Manajemen, 3(1), 40-48. 
Rosiana, G., Juliarsa, G., and Sari, M. (2013). Pengaruh pengungkapan CSR terhadap nilai perusahaan dengan profitabilitas sebagai variabel pemoderasi. E-Jurnal Akuntansi, 723728.

Rozuel, C. (2013). Social Contract. Encyclopedia Of Corporate Social Responsibility, 2193-2199. https://doi.org/10.1007/978-3-642-28036-8_525

Sahut, J.-M., Peris-Ortiz, M., and Teulon, F. (2019). Corporate social responsibility and governance. Journal of Management and Governance, 23(4), 901-912. https://doi.org/https://doi.org/10.1007/s10997-019-09472-2

Sharfman, M. P., and Fernando, C. S. (2008). Environmental Risk Management And The Cost Of Capital. Strategic Management Journal, 29, 569-592. https://doi.org/https://doi.org/10.1002/smj

Steijvers, T., and Voordeckers, W. (2009). Private Family Ownership and the Agency Costs of Debt. Family Business Review, 22(4), 333-346. https://doi.org/10.1177/0894486509338291

Tarigan, J., and Samuel, H. (2014). Pengungkapan Sustainability Report dan Kinerja Keuangan. Jurnal Akuntansi Dan Keuangan, 16(2), 88-101. https://doi.org/https://doi.org/10.9744/jak.16.2.88-101

USSIF. (2019). The Forum for Sustainable and Responsible investment. https://www.ussif.org/sribasics

Vitolla, F., Raimo, N., Rubino, M., and Garzoni, A. (2019). How pressure from stakeholders affects integrated reporting quality. Corporate Social Responsibility and Environmental Management, 26(6), 1591-1606.

Widyasari, N. A. (2015). Pengaruh Good Corporate Governance (GCG) Dan Pengungkapan Corporate Social Responsibility (CSR) Terhadap Nilai Perusahaan (Studi Pada Perusahaan Manufaktur Yang Terdaftar Di BEI Periode 2011-2013). Jurnal Administrasi Bisnis, 26(1).

Wulandari, P. P., and Atmini, S. (2012). Pengaruh tingkat pengungkapan wajib dan pengungkapan sukarela terhadap biaya modal ekuitas. Jurnal Akuntansi Multiparadigma, 3(3), 334-501.

\section{JRAK}

